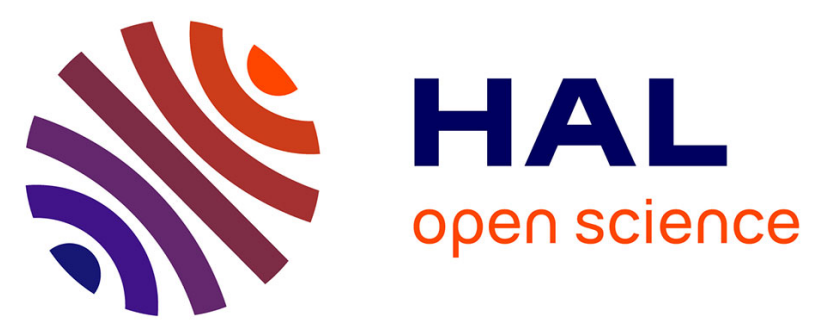

\title{
Lead Isotopic Composition of Fly Ash and Flue Gas Residues from Municipal Solid Waste Combustors in France: Implications for Atmospheric Lead Source Tracing.
}

Jean Carignan, Guy Libourel, Christophe Cloquet, Lydie Le Forestier

\section{To cite this version:}

Jean Carignan, Guy Libourel, Christophe Cloquet, Lydie Le Forestier. Lead Isotopic Composition of Fly Ash and Flue Gas Residues from Municipal Solid Waste Combustors in France: Implications for Atmospheric Lead Source Tracing.. Environmental Science and Technology, 2005, 39, pp.7, 2018-2024. 10.1021/es048693x . hal-00023362

\section{HAL Id: hal-00023362 \\ https://hal-insu.archives-ouvertes.fr/hal-00023362}

Submitted on 29 May 2006

HAL is a multi-disciplinary open access archive for the deposit and dissemination of scientific research documents, whether they are published or not. The documents may come from teaching and research institutions in France or abroad, or from public or private research centers.
L'archive ouverte pluridisciplinaire HAL, est destinée au dépôt et à la diffusion de documents scientifiques de niveau recherche, publiés ou non, émanant des établissements d'enseignement et de recherche français ou étrangers, des laboratoires publics ou privés. 


\title{
Lead Isotopic Composition of Fly Ash and Flue Gas Residues from Municipal Solid Waste Combustors in France: Implications for Atmospheric Lead Source Tracing.
}

\author{
JEAN CARIGNAN ${ }^{1 *}$, GUY LIBOUREL ${ }^{1,3}$, CHRISTOPHE CLOQUET ${ }^{1}$ AND LYDIE LE \\ FORESTIER $^{2}$.
}

1: CRPG-CNRS, UPR 2300, BP 20, 54501 Vandoeuvre-lès-Nancy, France.

2: ISTO (UMR 6113 CNRS-Université d’Orléans), Polytech’Orléans, 8 rue Léonard de Vinci, 45072 Orléans Cedex 2, France.

3: ENSG-INPL, BP 40, 54501 Vandoeuvre-lès-Nancy, France

* Corresponding author. Fax: (33) 3835117 98; e-mail: carignan@crpg.cnrs-nancy.fr

Fly ash and flue gas residues from eight municipal solid waste combusters (MSWC) in France (1992-93 and 1998-2002) were analysed for their Pb isotopic composition. Fly ashes are more representative of solid residual particles whereas flue gas residues reflect mostly the composition of gas phases. Both sample types contain hundreds to thousands of micrograms of metals per gram. Leaching experiments showed that metals are present in condensed phases, probably as sulfates and chlorides, and suggest that $\mathrm{Cd}, \mathrm{Pb}$ and $\mathrm{Zn}$ are highly fractionated from one another during volatilization/condensation processes occurring during combustion. Although all the samples analyzed define a fairly restricted range in $\mathrm{Pb}$ isotopic compositions $\left({ }^{206} \mathrm{~Pb} /{ }^{207} \mathrm{~Pb}=1.148-1.158\right.$ and $\left.{ }^{208} \mathrm{~Pb} /{ }^{206} \mathrm{~Pb}=2.101-2.114\right)$ compared to other environmental samples, some MSWC produce materials having distinct isotopic compositions, whereas others display very similar ones. Isotopic heterogeneity is also measured between samples from a single MSWC. This is interpreted as resulting from the heterogeneity of the waste source materials. The range of $\mathrm{Pb}$ isotopic composition of incinerator materials form a well-defined linear array in the ${ }^{208} \mathrm{~Pb} /{ }^{206} \mathrm{~Pb}$ versus ${ }^{206} \mathrm{~Pb} /{ }^{207} \mathrm{~Pb}$ diagram. This array is compatible with the previously reported European standard pollution (ESP) line and most probably represent the average lead isotopic composition of industrial atmospheric emissions in France, with the following ratios: ${ }^{206} \mathrm{~Pb} /{ }^{207} \mathrm{~Pb}=1.154 \pm 0.003$ and ${ }^{208} \mathrm{~Pb} /{ }^{206} \mathrm{~Pb}=2.107 \pm 0.003(1 \sigma)$. 


\section{Introduction}

Because of the continuous evolution of industries and anthropogenic activities, source emissions of metals to the atmosphere change through time. This affects the chemical and isotopic compositions of atmospheric metals, which are the result of mixing between the different sources. For example, the massive reduction of $\mathrm{Pb}$ addition to gasoline in North America in the early 1980's had a direct impact on the Pb isotopic composition of snow and ice in Greenland (1). Although source signature in Europe may be highly variable (2, 3), a change in the ${ }^{206} \mathrm{~Pb} /{ }^{207} \mathrm{~Pb}$ ratios measured in aerosols and rainwater sampled close to industrialised areas is also reported and interpreted as a change in relative contribution of emitters, gasoline and industries $(4,5)$. The $\mathrm{Pb}$ isotopic composition of such samples in France evolved with time toward the natural crustal composition, but the $\mathrm{Pb}$ excess (enrichment factor relative to crustal abundance, EF) present in these samples preclude a simple mixing between $\mathrm{Pb}$ emitted from gasoline combustion and natural $\mathrm{Pb}$. Moreover, Doucet and Carignan (6) suggested that $\mathrm{Pb}$ in aerosols, rainwaters, and epiphytic lichens from France, and probably western Europe, is a mixture between gasoline $\mathrm{Pb}$ and industrial $\mathrm{Pb}$ from other sources. The latter is certainly one of the dominant sources of $\mathrm{Pb}$ (and other metals) in the atmosphere today. Some aerosols from mountain areas have $\mathrm{Pb}$ concentration and isotopic composition suggesting a mixture between industrial and natural crustal $\mathrm{Pb}(4,6)$.

The chemical and isotopic characterization of "industrial $\mathrm{Pb}$ ” is not an easy task because of its possible extreme heterogeneity. Municipal solid waste combusters (MSWC) are certainly good to homogenize waste materials (7) and the flue gases emitted to the atmosphere may average the composition of several industrial sources. Indeed, municipal solid waste materials contain "second generation" industrial materials such as steel food cans or wires that are produced in different steel industries. MSWC materials may then represent one of the best proxies for averaging the composition of industrial $\mathrm{Pb}$ in products and goods available in France. Of course, a single industry may emit $\mathrm{Pb}$ to the atmosphere having a complete different isotopic composition than the average. On the other hand, MSWC represent themselves a significant source of metals to the atmosphere. Estimations of flux emissions worldwide (8) suggest that between $1 \%$ and $8 \%$ of the total annual emissions would come from the incineration of municipal wastes (gasoline combustion sources excluded). These percentages are confirmed in France, for which $\mathrm{Zn}, \mathrm{Cd}$, and $\mathrm{Pb}$ emissions from MSWC are estimated to represent $13 \%, 18 \%$, and $9 \%$, respectively, in $2002(9)$.

To characterize this source of emission, we analyzed the $\mathrm{Pb}$ isotopic composition of different samples from eight MSWC in France. Samples issued from different treatments were 
analyzed and leaching experiments were done in order to document any composition variations and to better constrain the composition of $\mathrm{Pb}$ emitted to the atmosphere from MSWC. To our knowledge, this is the first comprehensive study of waste incinerator materials for which the mineralogy and chemistry were already studied (10). We show that fly ashes and flue gas residues present small variations of their $\mathrm{Pb}$ isotopic composition and that the data allow us to constrain the average industrial $\mathrm{Pb}$ isotopic composition in France.

\section{Samples and Methods}

Samples were taken from eight MSWC covering the years 1992-1993, 1998, and 2002 and located in six different administrative regions of France (MSWC want to remain anonymous). For some MSWC, sampling covers several months. Depending of the fume treatment, the combustion of municipal solid wastes produces different and heterogeneous materials. Four types of materials were sampled. In a wet process (i) electrostatic precipitator ash (EP) was collected from electrofiltration of flue gas and (ii) filter cakes (FC) were condensed downstream in a scrubber that used water and lime. In a semidry process, (iii) scrubber residues (SR) were produced by injection of a lime slurry into the scrubber. In a dry process, (iv) fly ashes (FA) were settled by gravity in large funnels. Most samples were previously characterized for their chemical and mineralogical compositions $(10,11)$. These studies showed the extreme diversity of mineral phases such as silicates, oxides, alloys, chlorides, sulfates, carbonates, and silicate glasses, resulting from the no equilibrium conditions and the numerous phase transformations prevailing in the combustors.

The chemical composition of solutions from leaching experiments was directly measured by inductively coupled plasma (ICP) atomic emission spectroscopy (AES) on a Jobin Yvon JY 70 (Na, Ca, and K) and by ICP-mass spectrometry (MS) Perkin Elmer ELAN 5000 (Pb, Cd, and Zn) at the Service d'Analyse des Roches et des Minéraux (SARM, CRPG-CNRS). Uncertainty based on reproducibility is better than $2 \%$ for major cations and $5 \%$ for metals. Concentrations in solid samples, including those from refs 10 and 11 , were also determined at the SARM by ICP-AES and ICP-MS $(12,13)$. Samples were previously fused with $\mathrm{LiBO}_{2}$ and the glass was dissolved in a mixture of $\mathrm{HNO} 3\left(1 \mathrm{~mol} \mathrm{~L}^{-1}\right), \mathrm{H}_{2} \mathrm{O}_{2}(0.5 \% \mathrm{v} / \mathrm{v})$, and glycerol $(10 \%$ $\mathrm{v} / \mathrm{v}$ ) in order to obtain a dilution factor of 1000 relative to the amount of sample fused. Accuracy and reproducibility were checked by repeated measurement of international geological reference materials $(12,13)$, and uncertainty is better than $1-2 \%$ for major elements and $5 \%$ for trace elements. In all cases, experimental blanks were performed and found to be negligible compared to the elemental concentration measured in samples. The $\mathrm{Pb}$ isotopic 
composition of all samples was measured by MC-ICP-MS (IsoProbe Micromass, now GV Instruments). $\mathrm{Pb}$ was previously purified on anion-exchange resin according to the technique reported by Manhès et al. (14). Total Pb blank average was less than 1 ng and was negligible considering that between 1 and $10 \mu \mathrm{g} \mathrm{Pb}$ was processed through the column. The data acquisition was done in a multicollection static mode and the instrumental mass bias was corrected by use of a $\mathrm{Tl}$ spike of a known isotopic composition [National Institute of Standards and Technology (NIST) SRM 997, $\left.{ }^{203} \mathrm{Tl} /{ }^{205} \mathrm{Tl}=2.3889\right]$, as reported by Rekhämper and Mezger (15) and Thirlwall (16). Analyzing the NIST SRM $981 \mathrm{~Pb}$ isotope standard several times throughout the sessions of measurements controlled the accuracy and the reproducibility of the measurements. The exponential law was used to describe the mass bias relationship between isotopes. The $\mathrm{Tl}$ isotopic ratio of the reference solution was fixed instead of changing it in order to fit a through value for the NIST SRM $981 \mathrm{~Pb}$ as suggested by some authors (15). Rather, the relationship between $\mathrm{Tl}$ and $\mathrm{Pb}$ instrumental mass bias ( $\beta$ - $\mathrm{Tl}$ and $\beta-\mathrm{Pb})$ measured for the NIST SRM $981 \mathrm{~Pb}$ for a given analytical session was used to correct the $\mathrm{Pb}$ isotopic composition of unknown samples of the same session. The $\beta-\mathrm{Tl} / \beta-\mathrm{Pb}$ ratio may vary from one session to the another. This is the so-called "empirical" technique of mass bias correction introduced by Maréchal et al. (17) and applied to Pb isotopes by White et al. (18). Recalculated results obtained for the SRM 981 are compared to the ones reported by Thirlwall (16), obtained by thermal ionization (TI) MS and MC-ICP-MS with a double Pb spike or a Tl spike for the correction of instrumental mass fractionation (Table 1).

\section{Results}

More than 20 samples were analyzed for their bulk chemistry and lead isotopic composition. Table 2 presents average chemical compositions of each sample type. Furthermore, different treatments were done to samples in order to document any chemical and/or isotopic heterogeneity between solid/refractory phases and condensed gas phases.

Bulk Chemistry. MSCW solid residues comprise mainly calcium, silicon, aluminium, and chlorine as major elements (Table 2), with some variations according to the fume treatment (10, 11). Metal concentration varies from a few micrograms per gram (As, Co) to hundreds to thousands micrograms per gram for other heavy metals such as $\mathrm{Cd}, \mathrm{Zn}$, and $\mathrm{Pb}$. As observed for major and minor elements, no large variations are found between the different type of samples. Only filter cakes from the wet process have higher $\mathrm{Cd}, \mathrm{Cu}, \mathrm{Pb}, \mathrm{Sn}, \mathrm{Zn}$, and $\mathrm{Hg}$ concentrations 
than the other fly ashes, because these volatile heavy metals are concentrated in flue gases. Such a condensation process is also observed on fly ashes as shown by the presence of minute needles of salts such as $\mathrm{NaCl}, \mathrm{KCl}$, or $\mathrm{CaSO}_{4}$ on larger particles (Figure 1).

Leaching Experiments. According to the thermal regime of the MSWC, heavy metals in ashes should be partitioned between a residual and refractory component and a more volatile component probably represented by flue gas condensates. The chemical forms of metals in MSWC materials are poorly known. Thermodynamic calculations and physical observations by scanning electron microscopy (SEM) or X-ray diffraction indicate that some metals may be present as sulfate and chloride species (11). Water leaching of fly ashes should then easily dissolve condensed salts and give access to the heavy metal signature of the gaseous environments of the MSWC. This signature is important because it will characterize any atmospheric emission from the incinerator chimneys.

Chlorides are easily dissolved in distilled water, Cl dropping from $6 \mathrm{wt} \%$ in a bulk EP material to 0.6 wt\% after being leached with water (11). Furthermore, the $\mathrm{Cl}$ concentration is often inversely correlated to the grain size of the electrostatic precipitation ash and scrubber residue samples, suggesting that gas condensation salts are more abundant on smaller ash particles because of their higher specific surface. A number of metals, especially the most volatile ones ( $\mathrm{Zn}, \mathrm{Cd}$, and $\mathrm{Pb}$ ) follow the same concentration patterns as $\mathrm{Cl}$ according to the particle grain size. Different electrostatic precipitation ash samples were then leached with distilled water. One gram of powdered sample was transferred into an inert plastic container along with $50 \mathrm{~mL}$ of distilled water and a magnetic stirrer. After a given leaching time (15 min-72 h), all samples were left for 15 min to allow the remaining powder to settle. Between 10 and $20 \mathrm{~mL}$ of solution was then filtered to $0.45 \mu \mathrm{m}$ and analyzed for dissolved major cations (ICP-AES) and trace metals (ICP-MS). Results for a representative sample are reported in Table 3. The concentration of leached $\mathrm{Na}$ and K slightly increased with time. In contrast, Ca content in the first leach fraction (15 min) is significantly lower than in the following ones (Figure 2a). This may be explained if $\mathrm{Ca}$ is partitioned between different salts species, for example, chlorides and sulfates, having different dissolution kinetics. On the other hand, metal concentrations in leachates decrease significantly with time (Figure 2b). This is probably because of readsorption of metals on suspended particles as the $\mathrm{pH}$ of the distilled water increase from 5.2 to 8 during exchange with the sample. Furthermore, the relative proportion of extractable metals, presumably in condensed salts, varies greatly between $\mathrm{Pb}, \mathrm{Cd}$, and $\mathrm{Zn}$. Cadmium is by far the most enriched with almost 20\% of total Cd present in the 15 min leachate, followed by Zn, with 
up to 1.4 , and $\mathrm{Pb}$, with up to $0.3 \%$ (Table 3 ). As a result, the $\mathrm{Cd} / \mathrm{Pb}$ mass ratio changed from around 0.04 in the bulk fraction of electrostatic precipitation ash to 2.6-4.9 in the 15 min leachates for three selected samples (Table 4).

Pb isotopes. All the $\mathrm{Pb}$ isotope results are reported in Table 5. The different types of samples are grouped according to the administrative region and the combustors they come from. As a whole, the $\mathrm{Pb}$ isotopic composition of all samples from the different MSWC is fairly homogeneous nad comparable to data reported in the literature $(7,19)$ for similar samples. For example, the average ${ }^{206} \mathrm{~Pb} /{ }^{207} \mathrm{~Pb}$ ratio is $1.154 \pm 0.003$ (standard deviation from the mean) and ${ }^{208} \mathrm{~Pb} /{ }^{206} \mathrm{~Pb}$ ratio is $2.107 \pm 0.003$. On the other hand, the $\mathrm{Pb}$ content is highly variable, with concentrations varying from 1700 to $12000 \mu \mathrm{g} / \mathrm{g}$, with no correlation with the isotopic composition. Although the total range in isotope ratios is small, it is still at least 10 times larger than the external reproducibility obtained on the SRM $981 \mathrm{~Pb}$ sample (Table 1). This high precision allows the possibility to distinguish different MSWC and different samples from a single MSWC.

The results on all samples are reported in the ${ }^{208} \mathrm{~Pb} /{ }^{206} \mathrm{~Pb}$ versus ${ }^{206} \mathrm{~Pb} /{ }^{207} \mathrm{~Pb}$ diagram (Figure 3). Results from individual MSWC define distinct compositional fields and may be grouped according to their respective administrative region. For example, samples from MSWC from regions 2 and 6 are significantly different from samples collected from region 4. On the other hand, MSWC from different regions, not necessarily close one to another, may produce materials having the same or very similar $\mathrm{Pb}$ isotopic composition, suggesting a good average of available goods and products containing $\mathrm{Pb}$ and a traceable composition on a national scale. However, the $\mathrm{Pb}$ isotopic composition may vary significantly within a single incinerator, according to the type of sample (e.g., electrostatic precipitation ash, filter cakes, grain size, leachates) and the sampling time. Samples from several MSWC are reported in the ${ }^{207} \mathrm{~Pb} /{ }^{204} \mathrm{~Pb}$ vs ${ }^{206} \mathrm{~Pb} /{ }^{204} \mathrm{~Pb}$ and ${ }^{208} \mathrm{~Pb} /{ }^{204} \mathrm{~Pb}$ vs ${ }^{206} \mathrm{~Pb} /{ }^{204} \mathrm{~Pb}$ diagrams (Figure 4, panels a and $\mathrm{b}$, respectively). There is a significant difference in $\mathrm{Pb}$ isotopic composition between the ash and the related filter cake samples, the later having more radiogenic compositions. Isotope variations are also observed between bulk and leached fractions. However, the measured shift is not systematically in the same direction, leached fractions having lower ${ }^{208} \mathrm{~Pb} /{ }^{204} \mathrm{~Pb}$ and ${ }^{206} \mathrm{~Pb} /{ }^{204} \mathrm{~Pb}$ than the bulk samples for MSWC 3 and the contrary for MSWC 4. In addition, $\mathrm{Pb}$ in coarse grains $(200-500 \mu \mathrm{m})$ from the ash sample 1a is significantly less radiogenic than the related finer fractions $(<200 \mu \mathrm{m}$; see Table 5). Samples collected through time from a single 
MSWC show also an isotopic variability. These variations are observed for all types of samples and are rather erratic as they do not show any systematic variation with time. Although generally smaller, isotopic variations within a single MSWC may be as large as those observed between different MSWC.

\section{Discussion}

The leaching experiments showed that $\mathrm{Cd}, \mathrm{Zn}$, and $\mathrm{Pb}$ have different behaviors during evaporation-condensation processes prevailing in MSWC. Indeed, highly volatile Cd may be easily leached from ash particles, representing up to $20 \%$ of the total $\mathrm{Cd}$. High $\mathrm{Na}$, K, and Ca but also $\mathrm{Cl}$ and probably sulfate $(10,11)$ concentrations in these leach fractions suggest that the extractable metals are associated with condensed salts so that they were previously in a gas phase. Less volatile than $\mathrm{Cd}$, extractable $\mathrm{Pb}$ condensed on ash particles represents only $0.3 \%$ of total. Nonetheless, this gas $\mathrm{Pb}$ is probably the phase able to reach the atmosphere most easily. For this reason, it is important to characterize the isotopic composition of this gas phase. More controlled leaching experiments should give access to a more constrained definition of metal speciation in MSWC materials.

Isotopic Heterogeneity of Waste Incineration Materials. In this discussion, we assume that the $\mathrm{Pb}$ analyzed from the leach fractions and filter cake samples represents the composition of the gas $\mathrm{Pb}$ phase. A difference in the isotopic composition between the solid and gas phases may result either from an isotopic fractionation of $\mathrm{Pb}$ during the volatilization or from the fact that these phases have distinct sources with slightly different isotopic signatures. Data from MSWC reported in Figure 4 are not following the theoretical mass fractionation line for 204-206-207-208 $\mathrm{Pb}$ isotopes but rather form a steeper slope in the ${ }^{207} \mathrm{~Pb} /{ }^{204} \mathrm{~Pb}$ versus ${ }^{206} \mathrm{~Pb} /{ }^{204} \mathrm{~Pb}$ diagram and a flatter slope in the ${ }^{208} \mathrm{~Pb} /{ }^{204} \mathrm{~Pb}$ versus ${ }^{206} \mathrm{~Pb} /{ }^{204} \mathrm{~Pb}$ diagram. On the basis of these observations, along with the fact that isotopic variations measured are large and not always in the same direction with respect to bulk samples, we suggest that the observed isotopic variations are not the result of mass fractionation of $\mathrm{Pb}$ during volatilization. Rather, the range in isotopic ratio results from the heterogeneous feeding waste materials. Indeed, we may think of having more or less refractory materials in the MSWC, such as metals from cans and plastics or rubber. The later may be completely volatilized at high temperature (ca. $800^{\circ} \mathrm{C}$ and above), resulting in a nearly complete volatilization of heavy metals present in the material. Average $\mathrm{Pb}$ in such wastes may have an overall isotopic composition slightly different than 
residual-refractory $\mathrm{Pb}$, with either higher or lower ${ }^{204} \mathrm{~Pb}$ normalized ratios. This is also reflected by the day-to-day variations of the samples for a single MSWC.

Isotopic variations are also observed between MSWC from different regions (Figure 3). Although these variations are not easily correlated with the geographic location of the MSWC, they certainly reflect either different supplies in goods and other raw materials (cans, wires, etc.) or different use of these materials.

French MSWC Trend. Our results from eight MSWC located throughout the whole French territory define a coherent distribution in a $\mathrm{Pb}-\mathrm{Pb}$ isotope diagram (Figure 5a). For comparison, ash samples from Lille MSWC (sampled in 1996) in northern France (19) plot in the same trend whereas samples from Sete (sampled in 1993-1994) in southeastern France (7) do not define a good linear trend, with only one point being in the general array. This might simply reflect the heterogeneity of waste materials produced in France. It is, however, striking that eight MSWC (nine if Lille is included) define relatively well collinearity considering the variety of materials in both space and time (1992-2002). The MSWC trend defined in Figure 5a represents most probably the composition of $\mathrm{Pb}$ used in different goods and other consumable materials available in France.

In Figure 5b, the MSWC data are compared to the industrial $\mathrm{Pb}$ line and the European standard pollution (ESP) line (22). These lines were defined by data from the literature, mainly industrial materials, $\mathrm{Pb}$ from car exhausts, and some major ore deposits for the industrial $\mathrm{Pb}$ and materials integrating atmospheric Pb fallout in Europe for the ESP. The MSWC data plot very close to the ESP line and may then represent the average composition of anthropogenic $\mathrm{Pb}$ emitted in the atmosphere in France. Of course, any given industry may generate pollution $\mathrm{Pb}$ having a different isotopic composition than the MSWC materials (5). In addition, MSWC directly contribute for a significant part of the total $\mathrm{Pb}$ atmospheric emissions (8).

Regional/National Pb Sources. The Pb isotopic composition of fly ashes and flue gases are compared to that of French gasoline and some aerosols sampled in different space and time in France (Figure 6). Just like in North America, a change of the atmospheric $\mathrm{Pb}$ isotopic composition through time was observed for the last 20 years in western Europe $(4,5)$. This is illustrated by the shift observed for the composition of aerosols sampled near highways in France in 1984 and 1995 and in the city of Paris between 1989 and 1995 (5) (Figure 6). The data points in Figure 6 form a linear array and the materials from MSWC are located at the "radiogenic" end of the array, towards the displacements of compositions through time. This 
suggests that, as proposed in an earlier work (6), the relative proportions of gasoline combustion and industrial atmospheric emissions are changing toward a more important industrial contribution. The average isotopic composition of industrial emissions is well approximated by that of MSWC materials. According to the results presented in this study, we suggest the use of ${ }^{206} \mathrm{~Pb} /{ }^{207} \mathrm{~Pb}=1.154 \pm 0.003$ and ${ }^{208} \mathrm{~Pb} /{ }^{206} \mathrm{~Pb}=2.107 \pm 0.003$ as the best estimation for the average French industrial atmospheric emissions.

\section{Acknowledgments}

We express special thanks to SITA for sample donation. Christophe Raoul, and all the personnel of the Service d'Analyse des Roches et des Minéraux (SARM) of CNRS, are greatly thanked for their help in the preparation of samples and the measurement of elemental concentrations. The assistance of Xavier Framboisier for isotopic measurement was also greatly appreciated. This work was financially supported by the PRISM-EC grant to CRPG and by the SARM. This is CRPG contribution 1732.

\section{Literature cited}

(1) Rosman, K.J.R.; Chilsom, W.; Boutron, C.F.; Candelone, J.P.; Hong, S. Geochim. Cosmochim. Acta 1994, 58 (15), 3265.

(2) Hopper, J.F.; Ross, H.B.; Sturges, W.T.; Barrie, L.A. Tellus 1991, 43B, 45.

(3) Flament, P.; Bertho, M.-L.; Deboudt, K.; Veron, A.; Puskaric, E. Sci. Total Environ. 2002, 296, 35 .

(4) Grousset, F.E.; Quetel, C.R.; Thomas, B.; Buat-Menard, P.; Donard, O.F.X.; Bucher, A. Environ. Sci. Technol. 1994, 28, 1605.

(5) Véron, A.; Flament, P.; Bertho, M.L.; Alleman, L.; Flegal, R.; Hamelin, B. Atmosph. Environ. 1999, 33, 3377.

(6) Doucet, F.J.; Carignan, J. Atmosph. Environ. 2001, 35, 3681.

(7) Monna, F.; Lancelot, J.; Lewis, J.T. Environ. Sci. Technol. 1997, 31(8), 2277.

(8) Nriagu, J.O. ; Pacyna, J.M. Nature 1988, 133, 134.

(9) Centre Interprofessionnel Technique d’Etudes de la Pollution Atmosphérique. Emissions dans l'air en France 2004 ; http://www.citepa.org/pollution/index.htm.

(10) Le Forestier, L. ; Libourel, G. Environ. Sci. Technol. 1998,32, 2250.

(11) Le Forestier, L. Résidus ultimes de l'incinération des déchets ménagers. Caractérisation chimique et minéralogique, essais de stabilisation par vitrification et comportement à 
long terme des verres à la lixiviation. Thèse de l'Institut National Polytechnique de Lorraine, Nancy, France, 1996.

(12) Govindaraju, K.; Mevelle, G. J. Anal. At. Spectrom. 1987, 2, 615.

(13) Carignan, J. ; Hild, P. ; Mevelle, G. ; Morel, J. ; Yeghicheyan, D. Geostand. Newl. 2001, 25(2-3), 187.

(14) Manhès G.; Allègre C.J.; Dupré B.; Hamelin B. Earth Planet. Sci. Lett. 1980, 47, 370.

(15) Rekhämper, M.; Mezger, K. J. Anal. At. Spectrom. 2000, 15, 1451.

(16) Thirlwall, M.F. Chem. Geol. 2002, 184, 255.

(17) Maréchal, C.N.; Télouk, P.; Albarède, F. Chem. Geol. 1999, 156, 251.

(18) White, W.M. ; Albarède, F. ; Télouk, P. Chem. Geol. 2000, 167, 257.

(19) Deboudt, K.; Flament, P.; Weis, D.; Mennessier, J.-P.; Maquinghen, P. Sci. Total Environ. 1999, 236, 57.

(20) Verhaulst, D.; Buekens, A.; Spencer, P.J.; Eriksson, G. Environ. Sci. Technol. 1996, 30, 50 .

(21) Abanades, S. ; Flamant, G. ; Gagnepain, B. ; Gauthier, D. Waste Manage. Res. 2002, 20, 55.

(22) Haack, U.K.; Gutsche, F.H.; Plessow, K.; Heinrichs, H. Water, Air and Soil Pollut. 2002, 139, 261.

(23) Bollhöfer, A.; Rosman, K.J.R. Geochim. Cosmochim. Acta 2001, 65 (11), 1727.

(24) Roy, S. Utilisation des isotopes du Pb et du Sr comme traceurs des apports anthropiques et naturels dans les précipitations et les rivières du bassin de Paris. Thèse de Doctorat de l’Université Denis Diderot, Paris 7, et de l’Institut de Physique du Globe de Paris, 1996. 


\section{Figure captions.}

Figure 1. Microphotograph of a fly ash particle on which minute white needles are present. These represents condensed flue gases, including metals previously present as a gas phase.

Figure 2. Diagrams showing the major (a) and metal (b) dissolved ions in electrostatic precipitated ash leachates as a function of experiment duration. Whereas $\mathrm{Ca}$, Na and K contents increase rapidly to reach a plateau, metals continuously drop in concentration with time, probably because of readsorption in response to an increasing $\mathrm{pH}$ of the leach solution (distilled water, ca. 5.2-8) while reacting with the sample.

Figure 3. All the data in a $\mathrm{Pb}-\mathrm{Pb}$ isotope diagram form a linear array and are grouped according to their site location (administrative regions). Isotopic composition differences within and between sites most probably result from source heterogeneity.

Figure 4. Isotopic relationship between time related electrostatic precipitation ash (EP) and filter cake (FC) samples (MSWC 1) and between bulk (B) and leach (L) pairs of electrostatic precipitation ash samples (MSWC 3ab and 4) in (a) ${ }^{207} \mathrm{~Pb} /{ }^{204} \mathrm{~Pb}$ vs ${ }^{206} \mathrm{~Pb} /{ }^{204} \mathrm{~Pb}$ and (b) ${ }^{208} \mathrm{~Pb} /{ }^{204} \mathrm{~Pb}$ vs ${ }^{206} \mathrm{~Pb} /{ }^{204} \mathrm{~Pb}$ diagrams. The distribution of the data points does not follow the $\mathrm{Pb}$ isotope theoretical mass fractionation line. EP, electrostatic precipitated ash; FC, filter cake.

Figure 5. (a) Results from all MSWC (this study) compared to other data from the literature for French incinerators: Lille (19) and Sete (7). (b) Data from this study are compared to the European standard pollution (ESP) line and the industrial $\mathrm{Pb}$ line (22). Materials from most French MSWC yield Pb isotopic compositions very similar to the ESP.

Figure 6. In a ${ }^{207} \mathrm{~Pb} /{ }^{204} \mathrm{~Pb}$ vs ${ }^{206} \mathrm{~Pb} /{ }^{204} \mathrm{~Pb}$ diagram, results from MSWC samples are compared to the isotopic composition of aerosols collected in different cities of France $(5,23)$, French gasoline (7, 24), and aerosols collected near highways (5). Through time (1982-1998), the composition of many samples shifts toward that of MSWC materials, suggesting a higher proportion of "industrial" $\mathrm{Pb}$ than gasoline combustion $\mathrm{Pb}$ in the atmosphere. 
TABLE 1. Results Obtained on Pb NIST SRM 981 from This Study and from Literature ${ }^{\mathrm{a}}$

\begin{tabular}{|ccccc|}
\hline $\begin{array}{c}\text { NIST SRM 981 } \\
\text { Pb ratios }\end{array}$ & $\begin{array}{c}\text { MC-ICP-MS } \\
\begin{array}{c}\text { Tl norm } \\
\text { this study } \\
(\boldsymbol{n}=\mathbf{2 3})\end{array}\end{array}$ & $\begin{array}{c}\text { double spike } \\
\text { TIMS }^{\mathrm{c}}\end{array}$ & $\begin{array}{c}\text { double spike } \\
\text { MC-ICP-MS }^{\mathrm{c}}\end{array}$ & $\begin{array}{c}\text { MC-ICP-MS } \\
\text { Tl norm }^{\mathrm{c}, \mathrm{d}}\end{array}$ \\
${ }^{207} \mathrm{~Pb} / 206 \mathrm{~Pb}$ & $0.91463(4)$ & $0.91483(07)$ & $0.91488(08)$ & $0.91470(23)$ \\
${ }^{206} \mathrm{~Pb} / 204 \mathrm{~Pb}$ & $16.9440(28)$ & $16.9408(21)$ & $16.9417(29)$ & $16.9356(55)$ \\
${ }^{207} \mathrm{~Pb} / 204 \mathrm{~Pb}$ & $15.4978(18)$ & $15.4980(25)$ & $15.4996(31)$ & $15.4911(74)$ \\
${ }^{208} \mathrm{~Pb} / 204 \mathrm{~Pb}$ & $36.7298(52)$ & $36.722(08)$ & $36.724(09)$ & $36.697(23)$ \\
${ }^{200} \mathrm{~Pb} / 206 \mathrm{~Pb}$ & $2.16766(22)$ & $2.16768(23)$ & $2.16770(24)$ & $2.16686(68)$ \\
\hline
\end{tabular}

${ }^{\mathrm{a}}$ All errors are 2 times standard deviation from the mean. ${ }^{\mathrm{b}}$ Thallium (NIST SRM 997, ${ }^{205} \mathrm{Tl} /{ }^{203} \mathrm{Tl}=2.3889$ ) was used for mass fractionation correction (Pb/Tl from 10 to 12). ${ }^{c}$ From ref 16 . ${ }^{\mathrm{d}}$ Thallium (NIST SRM $997,{ }^{205} \mathrm{Tl} /{ }^{203} \mathrm{Tl}$ $=2.3889)$ was used for mass fractionation correction $(\mathrm{Pb} / \mathrm{Tl}$ from 3 to 30$)$. 
TABLE 2. Average Composition of Representative Sample Types ${ }^{\mathrm{a}}$

\begin{tabular}{|c|c|c|c|c|c|c|c|c|}
\hline \multirow{2}{*}{ element } & \multicolumn{2}{|c|}{$\begin{array}{c}\text { electrostatic } \\
\text { precipitator ash }^{\text {b }}\end{array}$} & \multicolumn{2}{|c|}{ filter cakes $^{b}$} & \multicolumn{2}{|c|}{$\begin{array}{l}\text { scrubber } \\
\text { residues }^{b}\end{array}$} & \multicolumn{2}{|c|}{ fly ashes $^{\mathrm{C}}$} \\
\hline & $n=10$ & SD & $n=10$ & SD & $n=8$ & SD & $n=8$ & SD \\
\hline \multicolumn{9}{|c|}{ Weight Percent Composition } \\
\hline $\mathrm{SiO}_{2}$ & 28.4 & 1.5 & 13.8 & 4.0 & 12.0 & 1.5 & 22.9 & 2.5 \\
\hline $\mathrm{Al}_{2} \mathrm{O}_{3}$ & 17.9 & 1.3 & 7.2 & 3.5 & 6.8 & 0.6 & 11.6 & 0.7 \\
\hline $\mathrm{Fe}_{2} \mathrm{O}_{3}$ & 1.8 & 0.3 & 2.2 & 0.6 & 1.2 & 0.1 & 2.2 & 0.2 \\
\hline $\mathrm{MgO}$ & 3.0 & 0.2 & 7.0 & 1.4 & 1.6 & 0.1 & 2.7 & 0.5 \\
\hline $\mathrm{CaO}$ & 23 & 1 & 22 & 2 & 38 & 3 & 30 & 2 \\
\hline $\mathrm{Na}_{2} \mathrm{O}$ & 3.7 & 0.4 & 0.2 & 0.1 & 2.0 & 0.2 & 3.3 & 0.8 \\
\hline $\mathrm{K}_{2} \mathrm{O}$ & 3.7 & 0.5 & 0.2 & 0.2 & 2.0 & 0.2 & 3.2 & 0.8 \\
\hline $\mathrm{TiO}_{2}$ & 1.8 & 0.1 & 0.6 & 0.3 & 0.7 & 0.1 & 2.0 & 0.1 \\
\hline $\mathrm{P}_{2} \mathrm{O}_{5}$ & 1.5 & 0.1 & 0.6 & 0.2 & 0.7 & 0.1 & 1.2 & 0.2 \\
\hline $\mathrm{CO}_{2}$ & 9.1 & 1.8 & 9.8 & 2.5 & 7.9 & 1.9 & 6.4 & 1.0 \\
\hline $\mathrm{Cl}$ & 7.4 & 0.9 & 10.9 & 2.0 & 17.6 & 1.6 & 5.5 & 0.3 \\
\hline $\mathrm{F}$ & 0.23 & 0.03 & 2.2 & 0.5 & 0.19 & 0.04 & 0.21 & 0.03 \\
\hline$S$ & 1.2 & 0.2 & 2.9 & 1.0 & 1.0 & 0.2 & 3.1 & 0.8 \\
\hline \multicolumn{9}{|c|}{ Micrograms per Gram Composition } \\
\hline As & 36 & 19 & 40 & 5 & 18 & 2 & 33 & 28 \\
\hline $\mathrm{Ba}$ & 1427 & 76 & 166 & 136 & 812 & 96 & 1684 & 377 \\
\hline $\mathrm{Cd}$ & 196 & 50 & 393 & 83 & 126 & 20 & 89 & 32 \\
\hline $\mathrm{Co}$ & 29 & 29 & 9 & 2 & 10 & 1 & 23 & 6 \\
\hline $\mathrm{Cr}$ & 496 & 89 & 264 & 93 & 221 & 26 & 492 & 74 \\
\hline $\mathrm{Cu}$ & 747 & 207 & 1168 & 123 & 437 & 37 & 574 & 111 \\
\hline $\mathrm{Ni}$ & 103 & 53 & 67 & 17 & 51 & 9 & 76 & 14 \\
\hline $\mathrm{Pb}$ & 3068 & 837 & 6547 & 1197 & 2780 & 316 & 2678 & 2115 \\
\hline Sn & 988 & 269 & 1942 & 304 & 814 & 106 & 687 & 265 \\
\hline $\mathrm{Zn}$ & 8030 & 1798 & 12730 & 2180 & 8211 & 1048 & 10785 & 2121 \\
\hline $\mathrm{Hg}$ & 20 & 8 & 824 & 198 & 18 & 5 & 0.3 & 0.1 \\
\hline
\end{tabular}

${ }^{\mathrm{a}}$ Sample types are described in the text. $n$, number of samples; SD, standard deviation from the mean. ${ }^{\mathrm{b}}$ Data from refs 10 and 11. 'Unpublished data from Cloquet Ph.D. thesis. 
TABLE 3. Major Cation and Metal Concentrations in Leachates of Sample Electrostatic Precipitated Ash $3 a^{a}$

\begin{tabular}{|c|c|c|c|c|c|c|c|c|c|}
\hline $\begin{array}{c}\text { time } \\
\text { (hour) }\end{array}$ & $\begin{array}{c}\mathbf{C a} \\
(\mathbf{m g} / \mathbf{L})\end{array}$ & $\begin{array}{c}\mathbf{N a} \\
(\mathbf{m g} / \mathbf{L})\end{array}$ & $\begin{array}{c}\mathbf{K} \\
(\mathbf{m g} / \mathbf{L})\end{array}$ & $\begin{array}{c}\mathbf{P b} \\
(\boldsymbol{\mu} \mathbf{g} / \mathbf{L})\end{array}$ & $\begin{array}{c}\mathbf{\%} \mathbf{P b} \\
\mathbf{e x t r a c t e d}\end{array}$ & $\begin{array}{c}\mathbf{C d} \\
(\boldsymbol{\mu} \mathbf{g} / \mathbf{L})\end{array}$ & $\begin{array}{c}\text { \%Cd } \\
\text { extracted }\end{array}$ & $\begin{array}{c}\mathbf{Z n} \\
(\boldsymbol{\mu g} / \mathbf{L})\end{array}$ & $\begin{array}{c}\text { \%Zn } \\
\text { extracted }\end{array}$ \\
\hline 0.25 & 396 & 567 & 589 & 757 & 0.32 & 1950 & 19.7 & 7468 & 1.41 \\
\hline 24 & 652 & 616 & 656 & 275 & 0.11 & 515 & 5.2 & 518 & 0.10 \\
\hline 48 & 675 & 630 & 673 & 172 & 0.07 & 234 & 2.4 & 146 & 0.03 \\
\hline 72 & 718 & 619 & 697 & 138 & 0.06 & 175 & 1.8 & 98 & 0.02 \\
\hline
\end{tabular}

${ }^{\mathrm{a}}$ One gram of powdered sample was leached with $50 \mathrm{~mL}$ of distilled water. 
TABLE 4. Bulk Composition of Electrostatic Precipitated Ash and Corresponding Leachates

\begin{tabular}{|c|c|c|c|c|c|c|c|c|c|}
\hline sample & $\begin{array}{c}\mathbf{P b} \\
(\mu \mathrm{g} / \mathrm{L})\end{array}$ & $\begin{array}{c}\text { Cd } \\
(\mu \mathrm{g} / \mathrm{L})\end{array}$ & $\begin{array}{c}\mathrm{Zn} \\
(\mu \mathrm{g} / \mathrm{L})\end{array}$ & $\mathrm{Cd} / \mathrm{Pb}$ & $\mathrm{Zn} / \mathbf{P b}$ & Zn/Cd & $\begin{array}{c}\mathrm{Cd} / \mathrm{Pb} \\
\text { leachate }\end{array}$ & $\begin{array}{c}\mathrm{Zn} / \mathrm{Pb} \\
\text { leachate }\end{array}$ & $\begin{array}{c}\mathrm{Zn} / \mathrm{Cd} \\
\text { leachate }\end{array}$ \\
\hline $3 a$ & 12000 & 494 & 26500 & 0.041 & 2.2 & 54 & 2.6 & 9.9 & 3.8 \\
\hline $3 b$ & 2750 & 129 & 5500 & 0.047 & 2.0 & 43 & 4.9 & 12.4 & 2.5 \\
\hline $3 c^{a}$ & 8300 & 362 & 19400 & 0.044 & 2.3 & 54 & 3.0 & 2.8 & 0.9 \\
\hline
\end{tabular}

${ }^{\mathrm{a}}$ Not analyzed for Pb isotopes. 
TABLE 5. Pb Isotopic Composition of MSWC Samples

\begin{tabular}{|c|c|c|c|c|c|c|c|c|c|c|}
\hline region & MSWC & $\begin{array}{l}\begin{array}{l}\text { sample } \\
\text { type }^{\mathrm{a}}\end{array} \\
\end{array}$ & fraction $(\mu \mathrm{m})$ & $\begin{array}{c}\text { sampling } \\
\text { date }\end{array}$ & ${ }^{206} \mathbf{P b} /{ }^{204} \mathbf{P b}$ & ${ }^{207} \mathbf{P b} /{ }^{204} \mathbf{P b}$ & ${ }^{208} \mathbf{P b} /{ }^{204} \mathbf{P b}$ & ${ }^{208} \mathbf{P b} /{ }^{206} \mathbf{P b}$ & ${ }^{206} \mathbf{P b} /{ }^{207} \mathbf{P b}$ & $\mathbf{P b}^{\mathrm{b}}(\mu \mathrm{g} / \mathrm{g})$ \\
\hline \multirow[t]{9}{*}{1} & $1 \mathrm{a}$ & $\mathrm{EP}$ & leach & 25/01/93 & 17.972 & 15.558 & 37.851 & 2.1060 & 1.1552 & 5250 \\
\hline & & $\mathrm{EP}$ & bulk & $1 / 10 / 93$ & 18.012 & 15.590 & 37.895 & 2.1039 & 1.1553 & 1950 \\
\hline & & EP & $200-500$ & $1 / 10 / 93$ & 17.925 & 15.587 & 37.815 & 2.1096 & 1.1500 & 1862 \\
\hline & & $\mathrm{EP}$ & $50-200$ & 1/10/93 & 18.014 & 15.595 & 37.900 & 2.1040 & 1.1550 & 1702 \\
\hline & & EP & $<50$ & 1/10/93 & 17.999 & 15.582 & 37.870 & 2.1040 & 1.1551 & 2438 \\
\hline & & FC & bulk & 25/01/93 & 18.017 & 15.588 & 37.915 & 2.1044 & 1.1558 & 6980 \\
\hline & & FC & bulk & $1 / 02 / 93$ & 18.034 & 15.587 & 37.933 & 2.1034 & 1.1570 & 7080 \\
\hline & & FC & bulk & 4/02/93 & 18.050 & 15.600 & 37.969 & 2.1035 & 1.1571 & 7070 \\
\hline & & FC & bulk & 1/10/93 & 18.031 & 15.601 & 37.941 & 2.1042 & 1.1558 & 6285 \\
\hline \multirow[t]{4}{*}{2} & $2 \mathrm{a}$ & SR & bulk & 1992 & 17.968 & 15.588 & 37.863 & 2.1072 & 1.1528 & 2740 \\
\hline & & SR & bulk & 29/01/93 & 17.914 & 15.585 & 37.813 & 2.1108 & 1.1494 & 3140 \\
\hline & & SR & bulk & 2/03/93 & 18.000 & 15.591 & 37.912 & 2.1062 & 1.1545 & 3020 \\
\hline & $2 b$ & SR & bulk & n.a. & 17.932 & 15.590 & 37.877 & 2.1121 & 1.1502 & 3560 \\
\hline \multirow[t]{4}{*}{3} & 3a & EP & bulk & 1992 & 18.019 & 15.596 & 37.962 & 2.1070 & 1.1552 & 12000 \\
\hline & & $\mathrm{EP}$ & leach & 1992 & 17.987 & 15.568 & 37.889 & 2.1064 & 1.1554 & - \\
\hline & $3 b$ & EP & bulk & 1992 & 18.011 & 15.598 & 37.961 & 2.1078 & 1.1547 & 2750 \\
\hline & & $\mathrm{EP}$ & $\begin{array}{l}\text { leach } \\
\text { bulk }\end{array}$ & 1992 & 18.001 & 15.586 & 37.929 & 2.1070 & 1.1549 & - \\
\hline \multirow[t]{4}{*}{4} & $4 a$ & EP & bulk & 9/12/98 & 18.028 & 15.595 & 37.939 & 2.1045 & 1.1560 & n.a. \\
\hline & & EP & leach & 9/12/98 & 18.033 & 15.603 & 37.962 & 2.1051 & 1.1558 & - \\
\hline & & EP & bulk & $16 / 12 / 98$ & 18.058 & 15.598 & 37.975 & 2.1031 & 1.1576 & n.a. \\
\hline & & EP & leach & $16 / 12 / 98$ & 18.062 & 15.607 & 37.991 & 2.1033 & 1.1573 & - \\
\hline 5 & $5 a$ & SR & bulk & 1992 & 18.012 & 15.595 & 37.954 & 2.1071 & 1.1550 & 3520 \\
\hline \multirow[t]{4}{*}{6} & $6 a$ & FA & bulk & $14 / 08 / 02$ & 17.955 & 15.604 & 37.904 & 2.1111 & 1.1507 & 1304 \\
\hline & & FA & bulk & 6/08/02 & 17.908 & 15.599 & 37.853 & 2.1138 & 1.1480 & 1990 \\
\hline & & FA & bulk & 8/08/02 & 17.919 & 15.603 & 37.860 & 2.1128 & 1.1485 & 1244 \\
\hline & & FA & bulk & $9 / 08 / 02$ & 17.950 & 15.607 & 37.893 & 2.1110 & 1.1501 & 1551 \\
\hline
\end{tabular}

${ }^{a}$ EP, electrostatic precipitation ash; FC, filter cakes; SR, scrubber residues; FA, fly ash. See text for descriptions. ${ }^{\mathrm{b} C o n c e n t r a t i o n ~ i n ~ t h e ~ b u l k ~ s a m p l e s ~ f r o m ~ r e f ~} 11$ and Cloquet (unpublished data). 


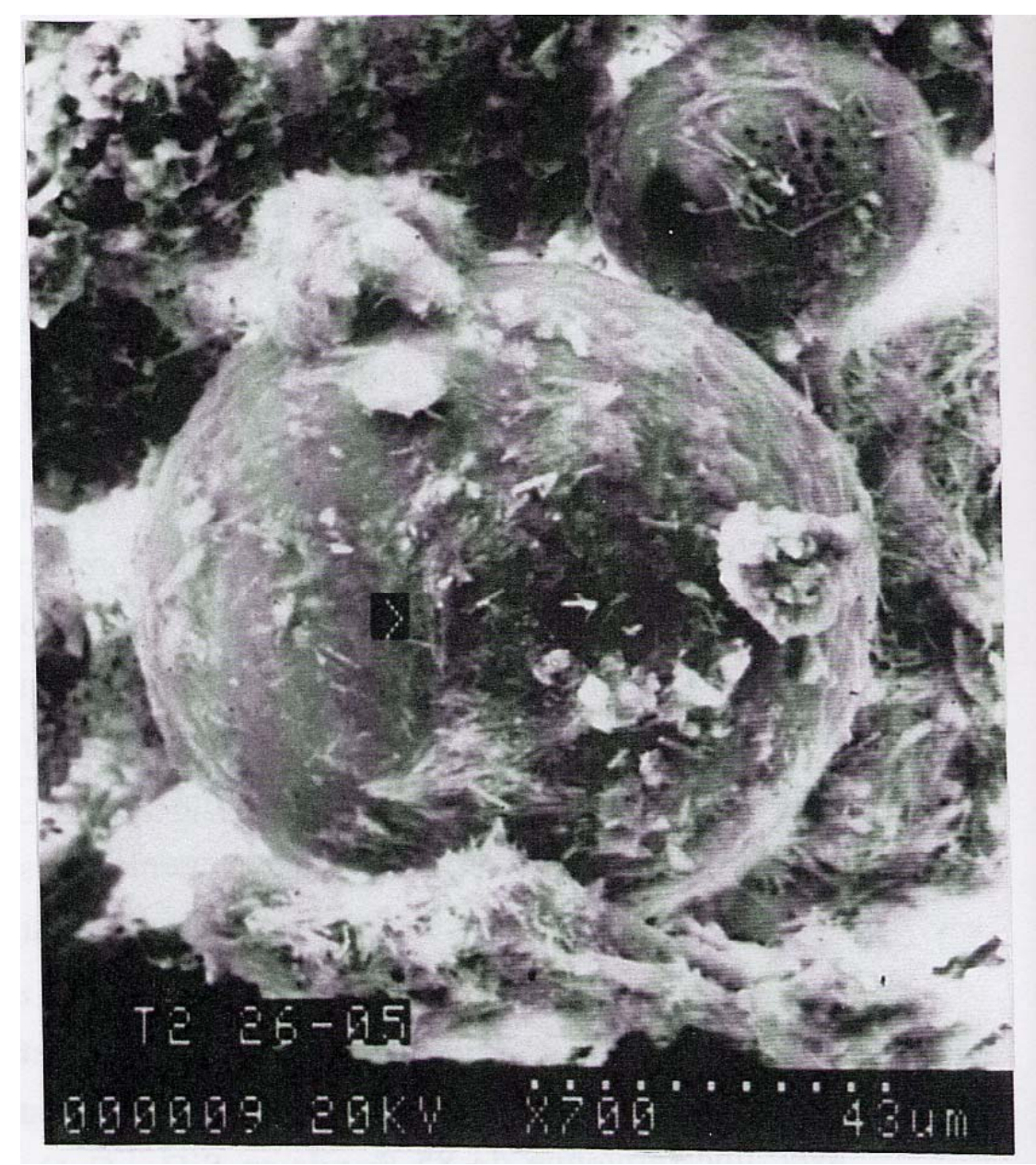

Figure 1

Carignan et al. 


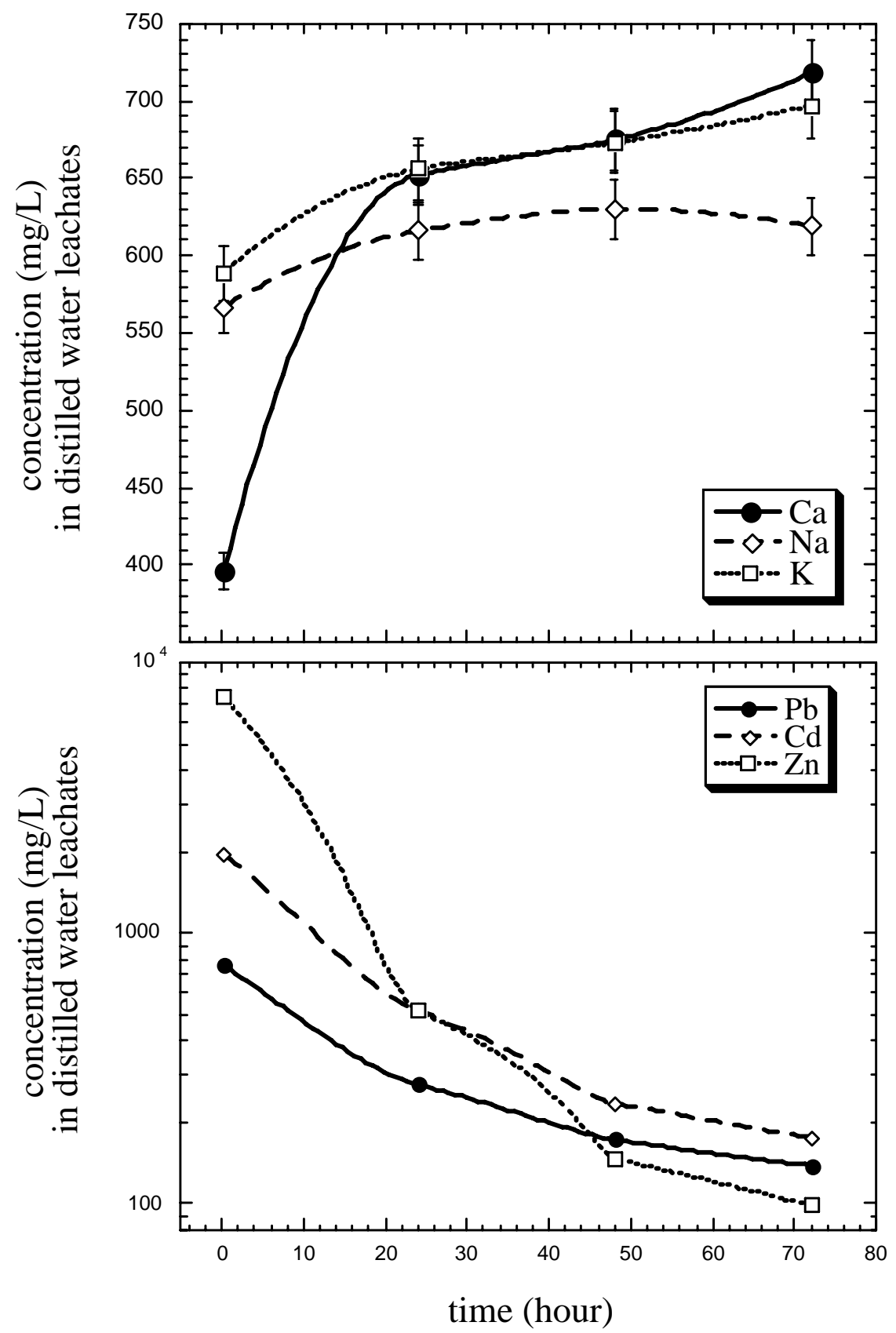

Figure 2

Carignan et al. 


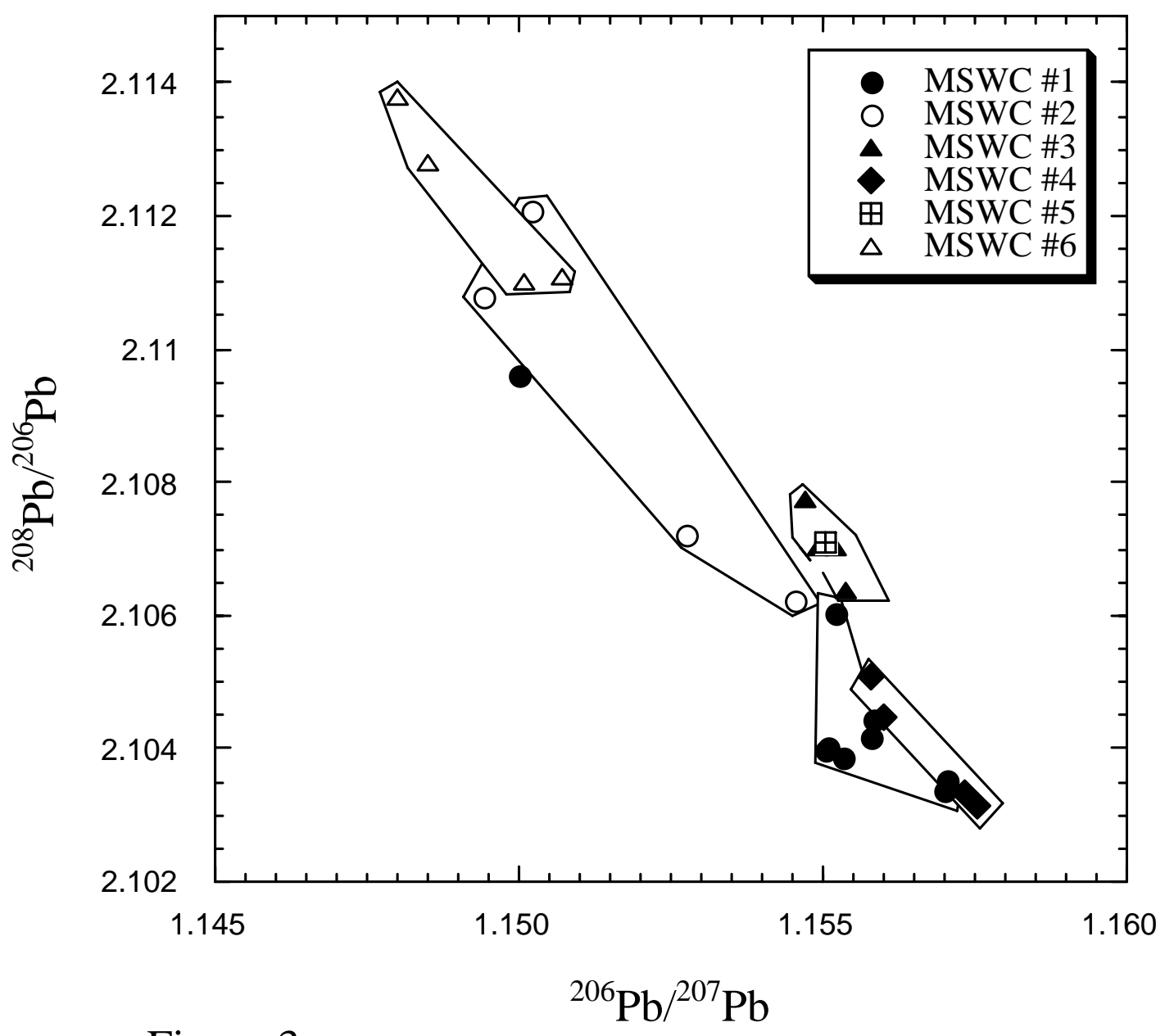

Figure 3

Carignan et al. 

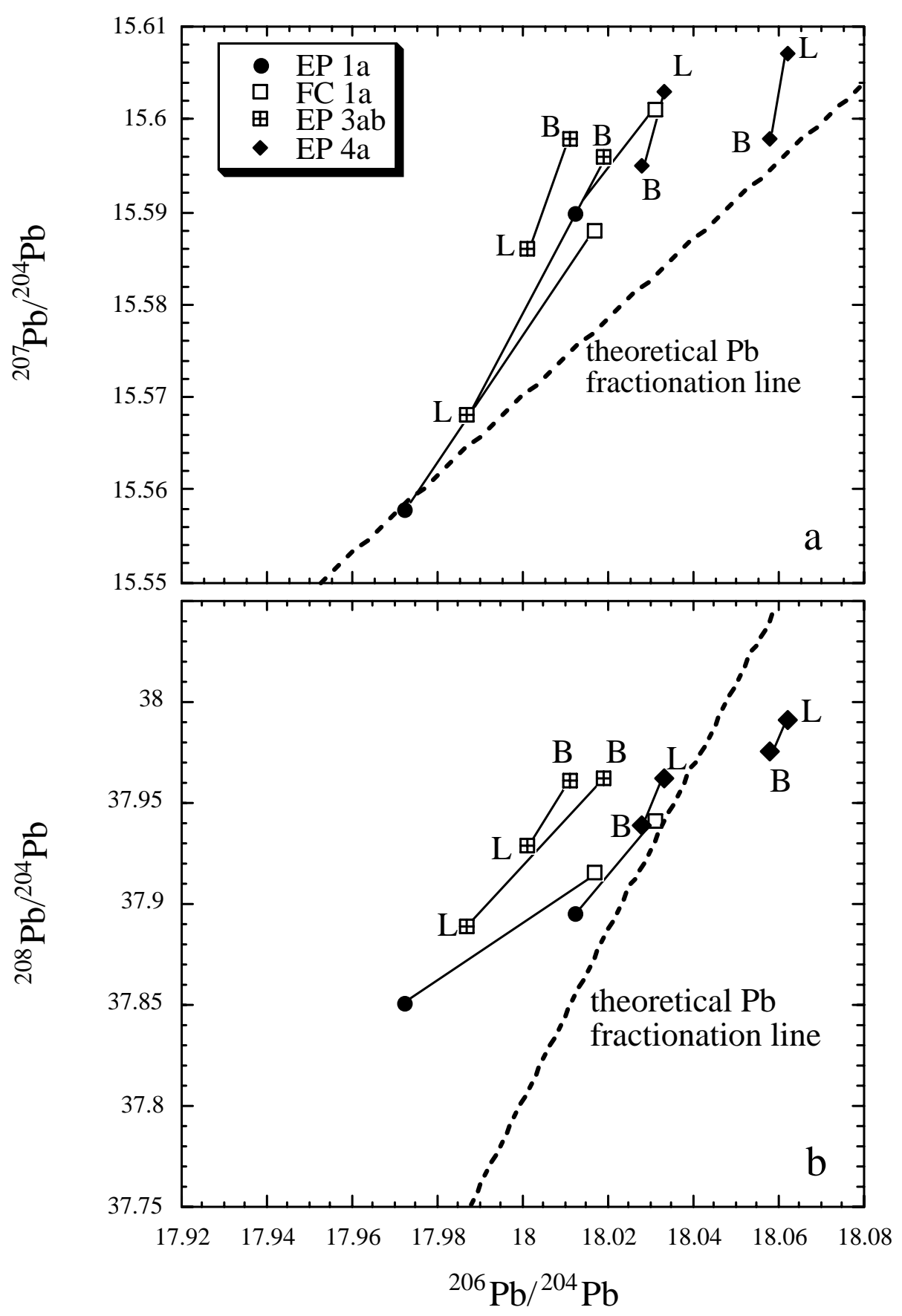

Figure 4

Carignan et al. 


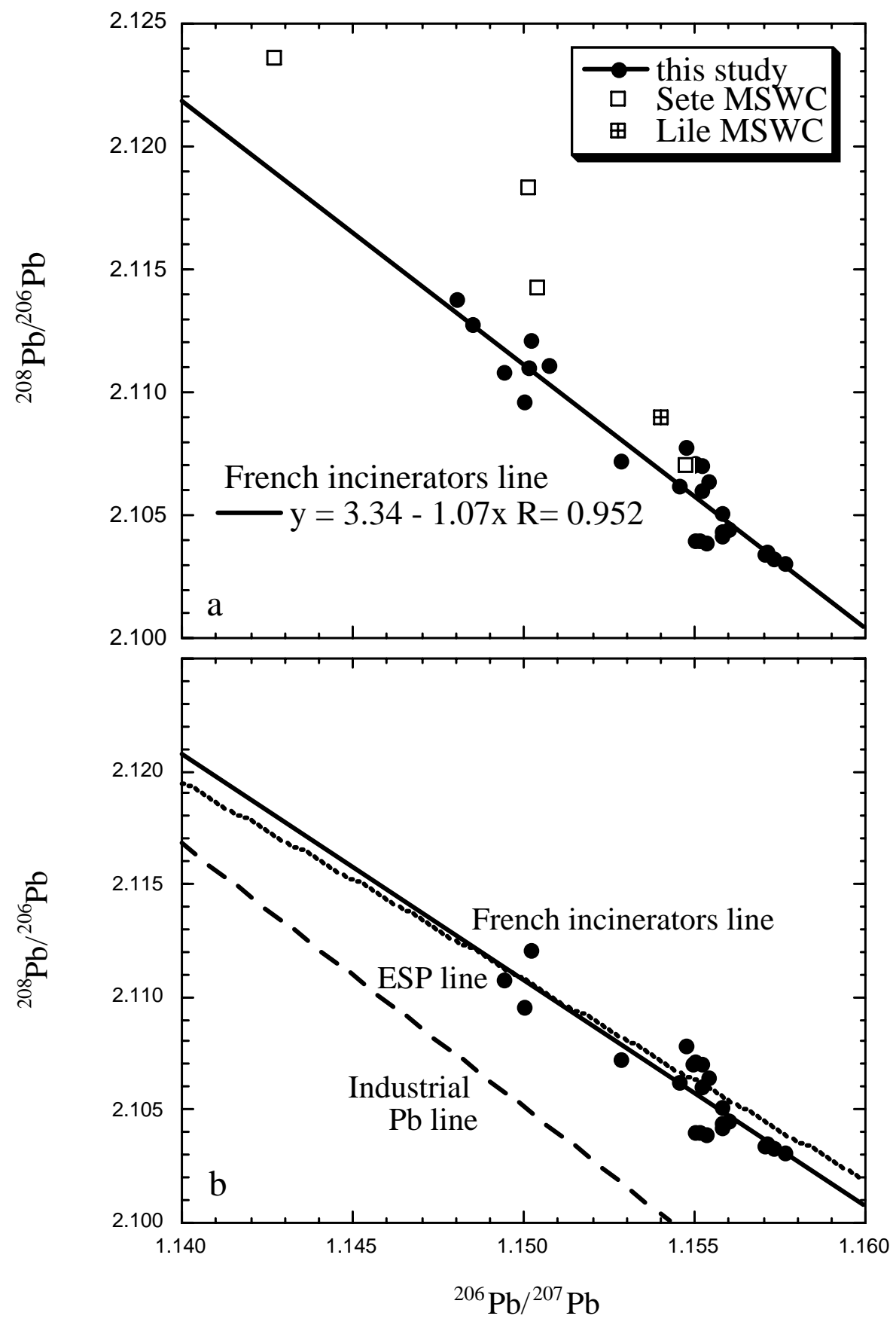

Figure 5

Carignan et al. 


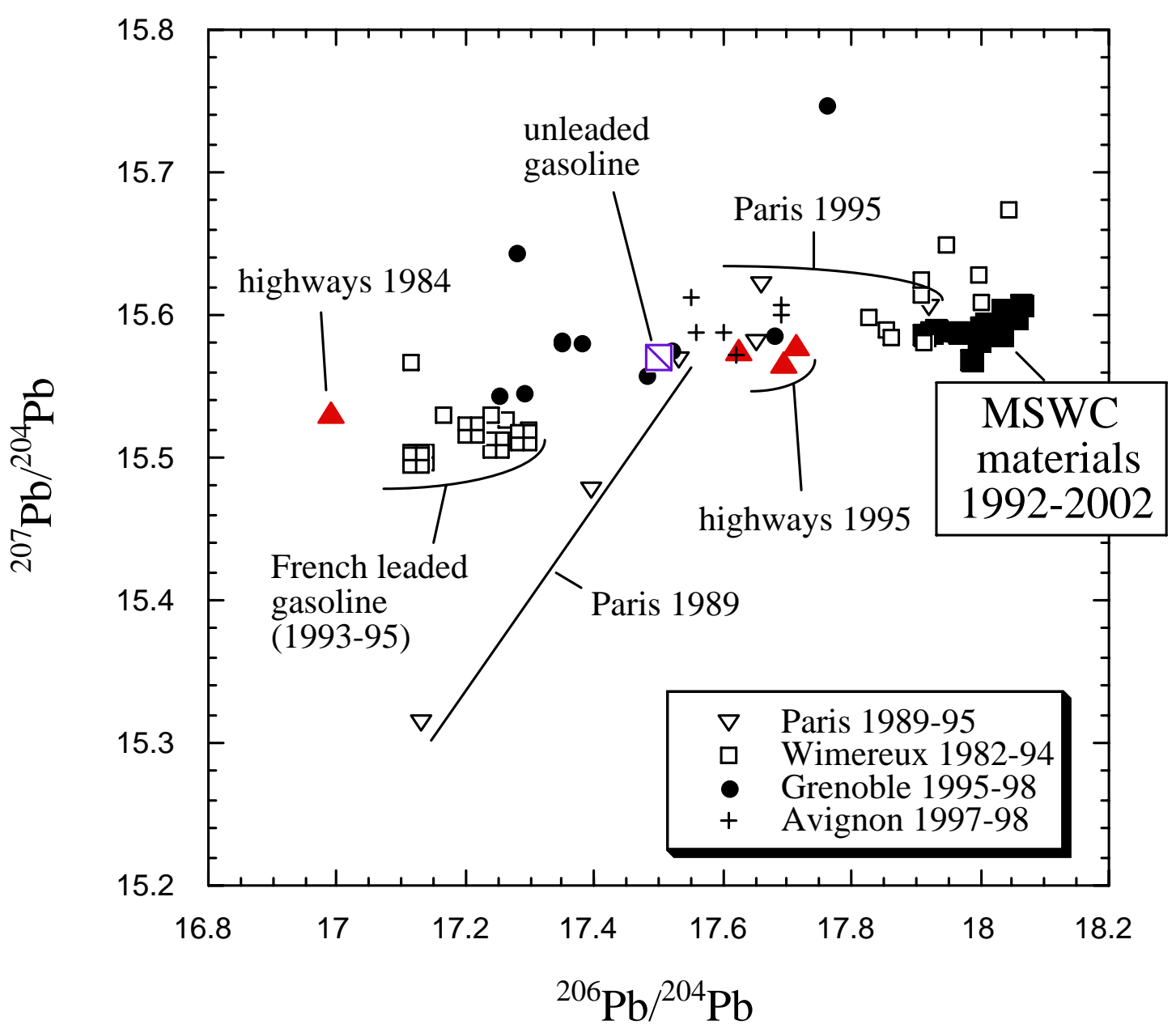

Figure 6

Carignan et al. 